\title{
リニアモータの支持機構として直線軸受を 用いた場合の軸受特性
}

$\begin{array}{llllll}\text { 正 員 } & \text { 水 } & \text { 野 } & \text { 勉 } & \text { (ア } & \text { タ }) \\ \text { 正 員 山 } & \text { 本 } & \text { 栄 } & \text { (アジア金属) } \\ \text { 正 員 山 } & \text { 由 } & \text { 一 (信 州大) }\end{array}$

Kinetic Behavior of Linear Motion Bearings Applied Linear Motor

Tsutomu Mizuno, Member (Amada Co., Ltd.), Shigeru Yamamoto, Member (Asia Metal Industry $\mathrm{Co}_{\text {, }}$ Ltd.), Hajime Yamada, Member (Shinshu University)

This paper deals with the kinetic behavior of linear motion bearings applied a permanent magnet type linear synchronous motor (LSM). It is necessary to make clear normal force characteristics of the LSM, because the normal force acts on the bearings and influences the life time of the bearings. Static thrust and normal force characteristics of the LSM were investigated from both sides of theory and experiment, and the nominal life of the bearings was investigated through the experimental transit. The results are as follows:

(1) The static thrust is $450 \mathrm{~N}$, and the normal force is $2.9 \mathrm{kN}$ at exciting current $8.8 \mathrm{~A}$. The normal force increases in proportion to exciting current, and shows constant value for displacement. The error of calculated value through finite element method is found within $20 \%$ of measured value of normal force.

(2) The acceleration arising from the bearings themselves is over $50 \mathrm{~m} / \mathrm{s}^{2}$. The maximum variable load generated by the acceleration reaches to $1.1 \mathrm{kN}$, and namely the ratio of the variable load is equal to $38 \%$ of the normal force.

(3) The nominal life of the bearings is calculated in $4,100 \mathrm{~km}$ with empirical load factor. In the test for durability, the LSM is driven in reciprocating motion at maximum speed $2 \mathrm{~m} / \mathrm{s}$, stroke length of $800 \mathrm{~mm}$. The distance of the test with periodic lubrication has been found over $16,000 \mathrm{~km}$. It will be necessary to reconsider the load factor of the linear motion bearings.

キーワード：リニアモータ, 永久磁石形リニア同期モータ, 直線軸受, 垂直力, 変動荷重, 有限要素法

\section{1.まえがき}

リニアモータの支持機跷を考慮する際，最も大きな 課題は，連続的に運動する可動子のエアギャップを長 期間安定して保持しなければならないことである。

片側式リニアモータに用いられる支持機構には, 垂 直力が作用するため，垂直力と支持機構について検討 する必要がある。垂直力を軽減するためん，両側式や 円筒状りニアモータも検討されている(1)。しかし、リ
ニアモータの機械装置への固定方法などに難点があ り，長ストローク化は困難である。

著者らは, FA 機器の高速化に伴い, 高速・高精度 位置決め能力を有し，長ストローク化が容易な片側式 の永久磁石形りニア同期モー夕（Permanent Magnet Type Linear Synchronous Motor, 以下 LSM) に着 目して，永久磁石形 LSM のサーボ化を行い，その推 力特性 ${ }^{(2)(3)}$ および垂直力特性を検郡してきだ(4)。

本論文は，リニアモータの支持機構として直線軸受 
を使用する場合の留意点について述へ，更に走行実験 を行った結果について考察したもので，以下の項目を 明かにしようとするものである。

（1）LSMの垂直力特性について, 実測と有限要 素法 (以下, FEM) による解析の両面から検討する。

（2）直線軸受に作用する加速度を測定すること で, 直線軸受に加わる変動荷重を明確にする。

（3）直線軸受の走行実験を行い, 経験的に得られ ている荷重係数を用いた軸受寿命の計算值と, 実走行 距離を比較することで荷重係数について検討する。

\section{2. 直線軸受に作用する荷重と LSM の構造}

\section{〈2・1〉直線軸受に作用する荷重と定格寿命}

図 1 は片側式りニアモータの直線軸受に作用する荷 重を表したものである。直線軸受はボール循環式直線 軸受で, 軸受ブロックと軸受レールから構成されてい る。同図中に示すように直線軸受には、リニアモータ の垂直力 $F_{z}$ と変動荷重 $F_{a}$ および自重 $F_{w}$ が作用する。 変動荷重は, 直線軸受に外部から作用するものと直 線軸受自身が発生するものに大別される。本論文は, 直線軸受自身が発生する変動荷重について着目してい る。直線軸受自身が発生する変動荷重は, 転動するボ ールが軸受ブロックと軸受レール間のサーキュラアー ク溝を通過するときに, ボールに作用する荷重が変化 することによって生ずる。この変動荷重は, 加速度 $a_{z}$ を発生させる。

変動荷重の最大值 $F_{a}$ おるび自重 $F_{w}$ は, それぞれ 次式から求めることができる。

$$
\begin{aligned}
& F_{a}=\left(m_{m}+m_{L}\right) \times a_{z} \quad(\mathrm{~N}) \\
& F_{w}=\left(m_{m}+m_{L}\right) \times a_{g} \quad(\mathrm{~N})
\end{aligned}
$$

ここ $\mathrm{k}, m_{m}, m_{L}:$ 可動子質量と積載質量

$(\mathrm{kg}), a_{z}$ ：軸受に作用する加速度の最大値

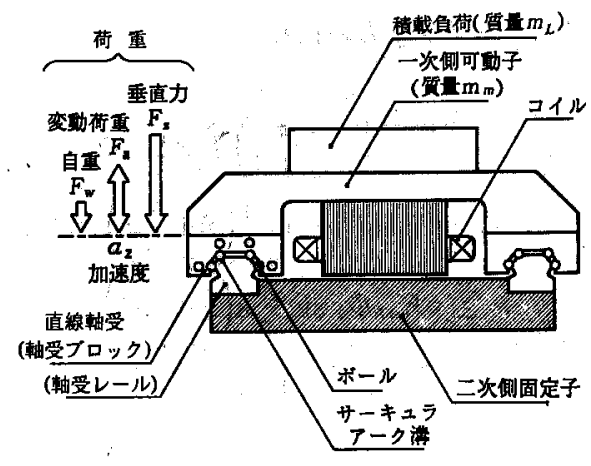

図 1 直線軸受に作用する荷重

Fig. 1. The loads acting on the linear motion bearings. $\left(\mathrm{m} / \mathrm{s}^{2}\right), a_{\theta}:$ 重力加速度 $\left(=9.8 \mathrm{~m} / \mathrm{s}^{2}\right)$

図 1 に示したように, 2 本の軸受レール上に配置さ れた 4 個の軸受ブロックで荷重を受ける場合, 軸受フ ロック 1 個当たりに作用する荷重 $P_{m}$ と直線軸受の定 格寿命 $L_{b}$ は, 次式で与えられている(5)。

$$
\begin{aligned}
& P_{m}=\left(F_{z}+F_{a}+F_{w}\right) / 4 \quad(\mathrm{~N}) \\
& L_{b}=50\left(\frac{f_{c} C}{f_{w} P_{m}}\right)^{3} \quad(\mathrm{~km}) \cdots \cdots
\end{aligned}
$$

ここに, $C:$ 直線軸受の基本動定格荷重

$(\mathrm{N}), f_{c}$ : 接触係数, $f_{w}$ : 荷重係数

上式に扔いて, 基本動定格荷重 $C$ は， 1 個の軸受ブ ロックで運転したとき，直線軸受の定格寿命が $L_{b}=$ $50 \mathrm{~km}$ となるような, 大きさの変動しない荷重のこと である。また，接触係数は 1 本の軸受レール内に 2 個 の軸受ブロックを近接して配置する場合の補正係数て $f_{c}=0.81$ である。更に, 荷重係数 $f_{w}$ は, 変動荷重が 正確に求められない場合用いる補正係数で, 経験的に $1 \sim 3.5$ の範囲にあり, 移動速度 $2 \mathrm{~m} / \mathrm{s}$ 以上では $f_{w}$ $=3$ とされている(5)。

〈2・2〉永久磁石形 LSM の構造 図 2 は永久磁 石形 LSM の構造と直線軸受に作用する垂直力を表し たものである。(a)図は永久磁石形 LSM の正面図 で, (b)図は側面図である。一次側は可動子で, 電磁 鋼板が積層された電機子鉄心に分布巻された三相巻線 が施されており，6極構造となっている。二次側（固 定子）のヨークには，一次側と対面する面が N,S 交 互になるように永久磁石か配置されている。

直線軸受はボール循環式直線軸受で, 軸受レールと 軸受プロックから構成されておりこの直線軸受に LSM の垂直力が作用する。直線軸受により, 一次側 と二次側間のギャップの長さは，0.7 mmに保たれて いる。

ブララットを介して，一次側フレームに固定された 回転形エンコーダのシャフトにはピニオンが取付けら れており，ラックとピニオンの作用により直線/回転 運動変換をし, 回転形エンコーダで可動子の位置検出 を行っている。

表 1 に永久磁石形 LSM の仕様を示す。同表に示す ように, ポールピッチ $\tau$ は $40 \mathrm{~mm}$, スロットピッチ て は $6.667 \mathrm{~mm}$ である。

永久磁石形 LSM をサーボモー夕として応用するた めには大きな推力が要求され, また直線軸受の耐久性 の観点から，軸受に作用する严直力が小さく，かつ励 磁電流の変化と一次側の移動に伴う垂直力の変動も少 ないことが望ましい。

ギャップの長さを大きくすることで垂直力を軽隇す 


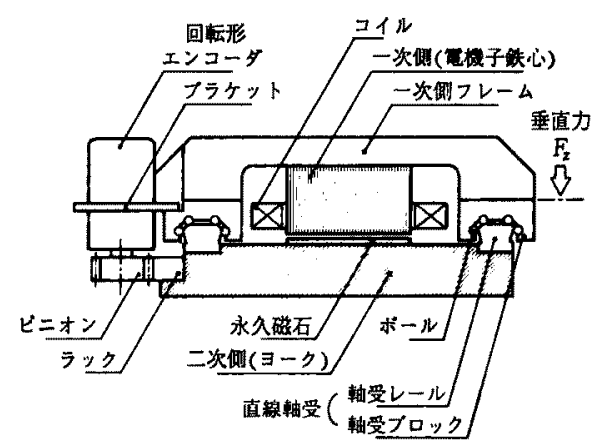

(a) 正面図

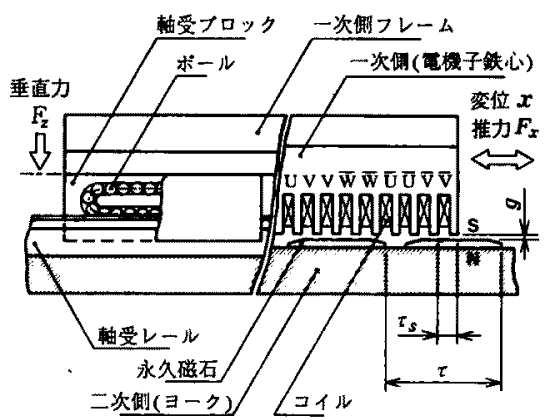

(b) 側面图

図 2 永久磁石形 LSM の構造

Fig. 2. Structure of a permanent magnet type LSM.

表 1 永久磁石形 LSM の仕様

Table 1. Specifications of the LSM.

\begin{tabular}{|c|c|c|c|c|}
\hline 項 & $\overline{\text { 目 }}$ & 記号 & 数值 & \\
\hline \multirow{6}{*}{$\begin{array}{l}\text { 一次溉 } \\
\text { (固定子) }\end{array}$} & 相数 & $m$ & 3 & 相 \\
\hline & 極数 & $P$ & 6 & 極 \\
\hline & コイル巻数 & $N$ & 216 & 回 \\
\hline & スロットピッチ & $\tau_{8}$ & 6.667 & $\mathrm{~mm}$ \\
\hline & 電機子鉄心の程層胉さ & $L$ & 68 & $\mathrm{~mm}$ \\
\hline & 電機子鉄心の長さ & $l$ & 243 & $\mathrm{~mm}$ \\
\hline \multirow{3}{*}{$\begin{array}{c}\text { 二次僋 } \\
\text { (固定子) }\end{array}$} & ポールピッチ & $\tau$ & 40 & $\mathrm{~mm}$ \\
\hline & 磁石の厚さ & $H$ & 3 & $\mathrm{~mm}$ \\
\hline & 磁石蛙 & $W$ & 34 & $\mathrm{~mm}$ \\
\hline \multicolumn{2}{|c|}{ ギャップの辰さ } & $g$ & \multicolumn{2}{|c|}{$0.7 \sim 1.1 \mathrm{~mm}$} \\
\hline
\end{tabular}

ることができるが,これに伴い推力も隇少する。そこ で表 1 に示したように,ギャップの長さを0.7〜 $1.1 \mathrm{~mm}$ および励磁電流を $0 \sim 8.8 \mathrm{~A}$ の範囲で変化さ せ, ギャップの長さと励磁電流が静推力および垂直力 に与える影跑について検討する。

〈2・3〉 駆動回路の構成 図 3 にLSM の駆動回 路の構成を示す。駆動回路は大別して，「位置速度制 御部」と「電流制御部」から構成されている。回転形

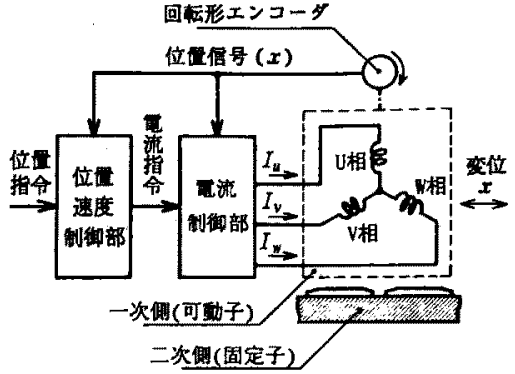

図 3 LSM の殹動回路の構成

Fig. 3. Constitution of a driving circuit for LSM.

エシコーダの位置信号は，それぞれの制御部にフィー ドバックされる。位置速度制御部は，位置指令および 位置信号に基づき電流指令を算出し電流制御部に与え る。電流制御部は, 一次側の変位 $x$ に対応して変化 する三相正弦波を作り，この三相正弦波と電流指令の 大きさに比例した三相正弦波電流 $I_{u}, I_{v}, I_{w}$ は，各コ イルに供給され，それぞれ次式で与えられる。

$$
\begin{aligned}
& I_{u}=\sqrt{2} I \sin \left(\frac{\pi}{\tau} x\right) \quad \text { (A) } \\
& I_{v}=\sqrt{2} I \sin \frac{\pi}{\tau}\left(x+\frac{2}{3} \tau\right) \\
& I_{w}=\sqrt{2} I \sin \frac{\pi}{\tau}\left(x-\frac{2}{3} \tau\right) \\
& \text { ここに，I：励磁電流 }(\mathrm{A}), \tau: \text { ポールピッチ } \\
& (\mathrm{m}), x: \text { 変位 }(\mathrm{m})
\end{aligned}
$$

\section{3. 垂直力特性}

\section{〈3・1〉 有限要素法による静推力と垂直力の解析}

静推力 $F_{x}$ の表現式は, 二次元非線形場の FEM(ベ クトルポテンシャル法) を用いて導出され，各相の発 生推力とディテントカの和として以下のように表され る(3)。

$$
\begin{aligned}
F_{x}= & -\frac{\sqrt{2} \pi}{\tau} N I\left\{\sin \left(\frac{\pi}{\tau} x\right) \sum_{n=1}^{\infty} n K_{w n} \Phi_{n}\right. \\
& \times \sin \left(\frac{\pi}{\tau} n x\right)+\sin \frac{\pi}{\tau}\left(x+\frac{2}{3} \tau\right) \\
& \times \sum_{n=1}^{\infty} n K_{w n} \Phi_{n} \sin \frac{\pi}{\tau} n\left(x+\frac{2}{3} \tau\right) \\
& +\sin \frac{\pi}{\tau}\left(x-\frac{2}{3} \tau\right) \\
& \left.\times \sum_{n=1}^{\infty} n K_{w n} \Phi_{n} \sin \frac{\pi}{\tau} n\left(x-\frac{2}{3} \tau\right)\right\} \\
& +\sum_{n=1}^{\infty} F_{d n} \sin \left(\frac{\pi}{\tau} n x\right) \text { (N) } \cdots \cdots
\end{aligned}
$$




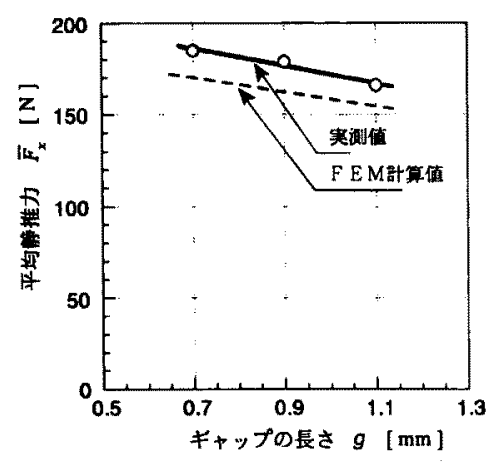

(a) 平均觧推力のギャップ传存性 (励磁流 $I=3.5 \mathrm{~A}$ )

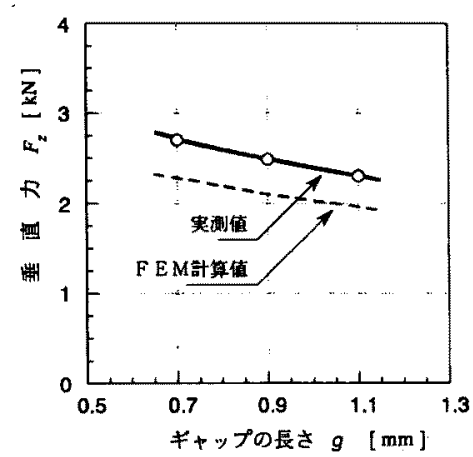

(b) 垂直力のギャップ依存性 (励磁電流 $I=0 \mathrm{~A}$, 変位 $x=0 \mathrm{~mm}$ )

図 4 平均静推力と垂直力のギャップ依存性

Fig. 4. Dependence of the static thrust and normal force on the gap length.

ここに, $N$ : 一相当たりのコイル巻数,

$K_{w n}$ : 第 $n$ 次高調波成分の巻線係数, $\Phi_{n}$ :

鎮交磁束の第 $n$ 次成分 $(\mathrm{Wb}), F_{\mathrm{d} n}$ : ディテ ント力の第 $n$ 次成分 $(\mathrm{N})$

更に, 平均静推力 $\bar{F}_{x}$ を下式て定義する。

$\bar{F}_{\boldsymbol{x}}=\left(F_{\max }+F_{\min }\right) / 2 \quad(\mathrm{~N})$

ここに, $F_{\max }$ : 静推力 $F_{x}$ の最大值 $(\mathrm{N})$,

$F_{\mathrm{m} n}$ : 静推力 $F_{x}$ の最小值 $(\mathrm{N})$

垂直力 $F_{z}$ は, 可動子全体を含む領域で，FEMを 用いてギャップの磁束分布を求め, 次にマクスウェル の応力法で計算した。

〈3-2〉垂直力特性永久磁石形 LSM には大き な静推力が要求され，また直線軸受の耐久性の観点か ら，軸受に作用する垂直力が小さく，かつ励磁電流の 変化および可動子の移動に伴う垂直力の変動も少ない ことが望ましい。重直力の変動は, 軸受に衝撃として 作用し軸受の寿命を低下させる要因の一つであるた

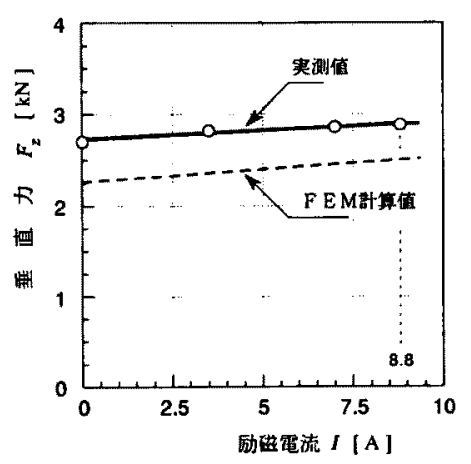

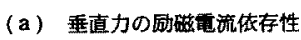
(変位 $x=0 \mathrm{~mm}$ )

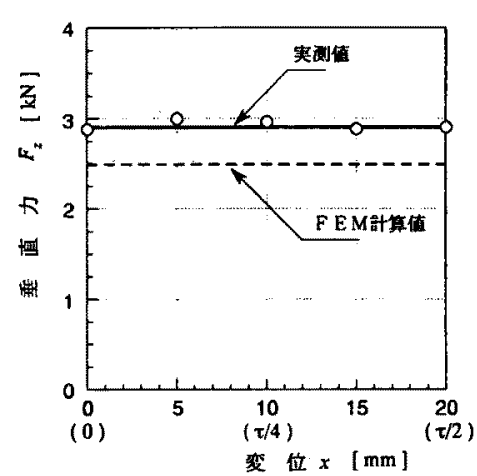

（b）垂直力の変位依存性 (动碳電流 $I=8.8 \mathrm{~A}$ )

図 5 垂直力の励磁電流と変位依存性 (ギャップの長さ $g=0.7 \mathrm{~mm}$ )

Fig. 5. Dependence of the normal force on the exciting current and displacement.

め(6)，垂直力の大きさとその変動を求めておくことは 重要なことである。ギャップの長さを大きくすること で垂直力を軽減できるが，推力も減少してしまう。

そこで，以下に示す項目に対して検討を行った。

（1）平均静推力と垂直力のギャップ依存性。

（2）励磁電流と一次側可動子の変位に対する垂直 力の変化。

図 4 は, 平均静推力と垂直力のギャップ依存性であ る。（a）図は励磁電流 $I=3.5 \mathrm{~A}$ における平均静推力 のギャップ依存性である。同図中に示した平均静推力 の実測值は，ギャップの長さに反比例している。 FEM による計算值は，まず(8)式により静推力を求 め, 次に(9)式で平均静推力を求めたものである。 FEM 計算值の計算誤差は, 実測值に対して $8 \%$ て ある。 
(b) 図は励磁電流 $I=0 \mathrm{~A}$, 変位 $x=0 \mathrm{~mm} に お け$ る垂直力のギャップ依存性である。垂直力の実測值 は，ギャップの辰さの二乗に反比例している。FEM 計算値はマクスウェルの応力法で求めたもので, 計算 誤差は夷湘值に対して $20 \%$ であ。垂直力の計算誤 差が大きな值となったのは, 一次側の側面からの漏れ 磁束を考慮していないためであると考えられる。

図 5 はギャップの長さ $g=0.7 \mathrm{~mm} に お け る$ 垂直力 の励磁電流と変位依存性である。(a)図は垂直力の励 磁電流依存性て, 垂直力は励磁電流に比例して増加 し, 電流を 0 から $8.8 \mathrm{~A}$ に変化させることで垂直力 は, $2.7 \mathrm{kN}$ から $2.9 \mathrm{kN}$ に約 $7 \%$ 增加している。励磁 電流 8.8A における平均静推力は $450 \mathrm{~N}$ で(3), 垂直力 は静推力の 6.4 倍となった。

(b)図は励磁電流 8.8Aにおける垂直力の変位依 存性である。同図は，変位によらず垂直力が $2.9 \mathrm{kN}$ と一定であることを示している。図 5 に示した FEM 計算値の計算愦差は約 $20 \%$ てある。

\section{4. 直線軸受に作用する荷重と走行実験}

〈4・1〉直線軸受に作用する变動荷重 LSM に 用いた直線軸受の仕様を表 2 に示す(5)。この直線軸受 はボール循環式玉軸受で, 基本動定格荷重 $12.5 \mathrm{kN}$, 軸受に用いられているボールの直径は $3.175 \mathrm{~mm} て ゙$ ある。

垂直力の変動と直線軸受自身が発生する変動荷重を 明確にするために, 直線軸受に作用する加速度を測定 した。

図 6 は, 一次側可動子を速度 $2 \mathrm{~m} / \mathrm{s}$ で駆動した場 合の直線軸受に作用する加速度の実測值である。これ は, 軸受ブロックの真上の一次側フレームに加速度ピ ックアップを瞬間接着材で固定し, 垂直力方向の加速 度を測定したものである。このときのギャップの長さ は $0.7 \mathrm{~mm}$ である。

図 6(a)は加速度波形で, その最大值は $50 \mathrm{~m} / \mathrm{s}^{2}$ 以 上にも達している。（b)図は加速度のパワースペクト ラムである。加速度のパワースペクトラムは, 周波数 $316 \mathrm{~Hz}$ の成分が最も大きく，またこの周波数の高調

\section{表 2 直線軸受の仕様}

Table 2. Specifications of the linear motion bearings.

\begin{tabular}{c|c|cc}
\hline 項 目 & 記 号 & \multicolumn{2}{|c}{ 数 } \\
\hline 基本值定格荷重 & $C$ & 12.5 & $\mathrm{kN}$ \\
\hline 基本静定格荷重 & $C_{0}$ & 25.2 & $\mathrm{kN}$ \\
\hline ホールの直径 & $d_{b}$ & 3.175 & $\mathrm{~mm}$ \\
\hline
\end{tabular}

波が主な成分となっている。更に，加速度の基本波周 波数は，転動するボールが軸受プックと軸受レール 間のサーキュラアーク汬（図 1参照）を通過するとき に, ボールに作用する荷重が変化することで発生する 振動の周波数 $315 \mathrm{~Hz}$ と一致する。このことから垂直 力方向の加速度は, 直線軸受が発生するものであるこ とがわかる。

なお,ポールピッチ $\tau=40 \mathrm{~mm}$ およびスロットピ ッチ $\tau_{s}=6.667 \mathrm{~mm}$ に起因する垂直力の変動成分，す なわち周波数 $50,300 \mathrm{~Hz}$ の加速度の成分は少ない。こ のことは, 図 5 に示したように, 一次側可動子の変位 による垂直力の変動が少ないことを旁付けている。

表 3 は直線軸受に作用する荷重である。変動荷重の 最大值 $F_{a}$ は，(1)式に可動子質量と積載質量の和 $22 \mathrm{~kg}$ 方よひ直線軸受に作用する加速度の最大値 50 $\mathrm{m} / \mathrm{s}^{2}$ を代入して求めた。同表に示すように, 直線軸

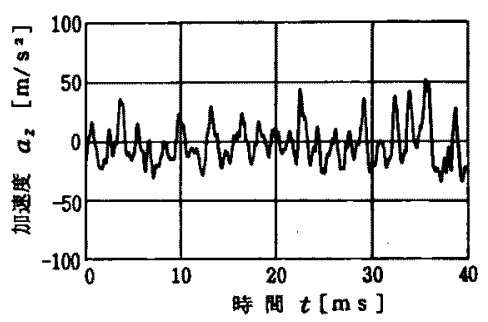

(a) 加速度波形

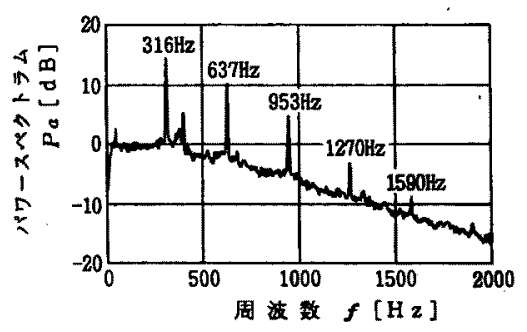

(b) 加速度のパワースペクトラム

図 6 直線軸受に作用する加速度 Fig. 6. Acceleration waveformes acting on the linear motion bearings.

表 3 直線軸受に作用する荷重 Tabl 3. The loads acting on the linear motion bearings.

\begin{tabular}{|c|c|c|c|}
\hline 項 目 & 記 昂 & 数 & \\
\hline 垂苜力 & $F_{2}$ & 2.9 & $\mathrm{kN}$ \\
\hline 変動荷重 & $F_{a}$ & 1.1 & $\mathrm{kN}$ \\
\hline 自重 & $F_{w}$ & 0.2 & $\mathrm{kN}$ \\
\hline
\end{tabular}




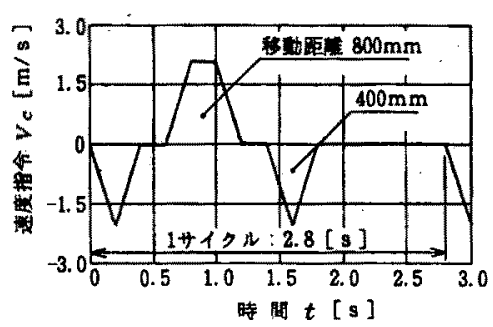

図 7 走行実験に用いたLSM の速度パターン (最高速度 $2 \mathrm{~m} / \mathrm{s}$ )

Fig. 7. A speed pattern of the LSM for experimental transit.

受自身が発生する変動荷重の最大值は, $1.1 \mathrm{kN} て ゙$, 垂直力 $2.9 \mathrm{kN}$ (励磁電流 $8.8 \mathrm{~A}$ ）に対して $38 \%$ と大 きな值となった。

〈4-2〉直線軸受の走行実験図 7 は直線軸受の 走行実験に用いた速度パターンである。加速度 $10 \mathrm{~m} /$ $\mathrm{s}^{2}$, 最高速度 $2 \mathrm{~m} / \mathrm{s}, 1$ サイクルの移動距離 $1.6 \mathrm{~m}$, 1サイクル 2.8 秒の駆動を行った。

また, 走行実験は室温 $25^{\circ} \mathrm{C}$ の恒温室でごみが軸受 に作用しない良好な環境条件で実施した。走行距離 $500 \mathrm{~km} こ ゙ と に ク ゙ リ ー ス{ }^{(7)}$ を軸受に給油し，LSM の速 度波形，励磁電流波形を測定した。約 1 年間の連続運 転を実施し，16,000 km の走行実験を行った結果，こ れら湘定值の変化および軸受の剥離現象は認められ ず，実用上また耐久性があることを確認した。

図 8 は荷重係数に依存する直線軸受の定格寿命の計 算值である。同図中に示した“変動荷重を考慮”は表 3 に示した直線軸受に作用する荷重を(4)式に代入し て求めた。また，“変動荷重を考慮しない”は，変動 荷重の最大值を $F_{a}=0 \mathrm{~N}$, すなわ金直力と自重だ けから算出したものである。

リニアモータの設計時に変動荷重を正確に算出する ことは困難であるから，図8の“変動荷重を考慮しな い”に示した特性から直線軸受の定格寿命を推定する ことになる。この場合, 移動速度 $2 \mathrm{~m} / \mathrm{s}$ で経験的に 得られている荷重係数 $f_{w}=3^{(5)}$ を用いると定格寿命の 計算値は 4,100 km となった。しかし，走行実験によ れば直線軸受の定格寿命は， $16,000 \mathrm{~km}$ 以上である。 この走行距離は, 荷重係数の経駼值 $f_{w}=3$ を用いた定 格寿命計算值 $4,100 \mathrm{~km}$ の 3.9 倍である。また, 図 8 中に示したように, 走行距離 $16,000 \mathrm{~km}$ は, 荷重係数 1.9 に相当する。

更に，図8の“変動荷重を考虑”に示した直線軸受

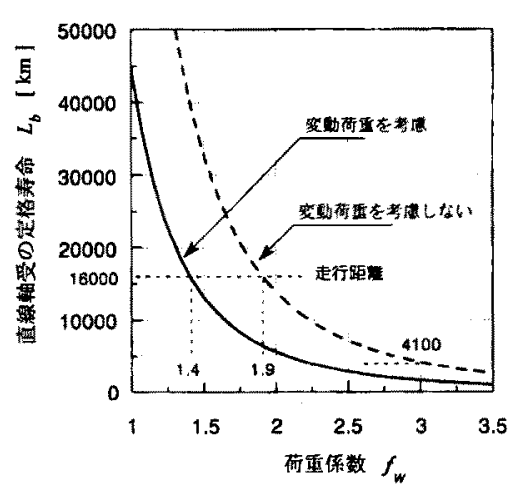

図 8 荷重係数に依存する直線軸受の定格 寿命の計算值

Fig. 8. Dependence of the calculated value of nominal life on the load factor of the linear motion bearings.

の定格寿命の計算值では, 走行距離 $16,000 \mathrm{~km}$ は荷重 係数 1.4 となった。

このように, 経験的に得られている荷重係数を用い ると直線軸受の定格寿命の計算値が大きな範囲にばら つくことになる。促って, 今後はこの荷重係数の再検 討が必要となるゔ。

\section{5.あとがき}

本論文では、リニアモータの支持機構として直線軸 受を用いる場合の留意点について述べた。直線軸受に 作用するLSM の垂直力と直線軸受自身が発生する変 動荷重について検討し，走行実験を行った。本論文で 得られた結果を要約すると以下のようになる。

(1) LSMの励磁電流8.8A に招ける平均静推力 は $450 \mathrm{~N}$, 垂值力は $2.9 \mathrm{kN} て ゙ あ り$, 垂直力は平均静 推力の 6.4 倍であった。また, 垂直力は励磁電流に比 例して普加するが，変位によらず一定であった。更 に，FEMによる垂直力の計算誤差は $20 \%$ ，一次側 可動子側面からの漏れ磁束も考慮する必要があること がわかった。

（2）直線軸受の構造に起因して軸受自身が発生す る加速度は $50 \mathrm{~m} / \mathrm{s}^{2}$ 以上であり，またこの加速度によ

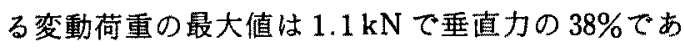
つた。

（3）移動速度から経験的に得られている荷重係数 $f_{w}=3$ を用いた場合の直線軸受の定格寿命計算値は， 4,100 kmであった。しかし，走行実験により 16,000 $\mathrm{km}$ 以上の耐久性があることを確認した。設計段階て 
定格寿命を高精度で推定するためには, 荷重係数にう いて多くの機関で再検討する必要がありそうである。

最後に，本研究について熱心な御討論をいただいた 電気学会搬送システム用リニアモー夕調查専門委員会 (委員長 武蔵工業大学 海老原助教授) の各委員に対し て深謝の意を表する。

(平成 3 年 10 月. 8 日受付, 同 4 年 5 月 20 日再受付)

\section{文献}

（1）リニア電磁駆動システム調查専門委員会：「リニア電磁駆動 システムの現状と応用技術」, 電気学会技報 (II 部), No. 314,6 (平元)

（2）水野・小俣：「永久磁石形 LSM の静推力解析」，電気学会リ ニアドライブ研资, LD-90-28, p. 1 (平 2)

（3）水野・山田：「永久磁石形リ二ア同期モ一夕の静推力特性」, 㫣学論 D, 111, 482 (平 3-6)

（4）水野・山本：「リニア同期モータに用いた循環式玉軸受の走 行実験報告」, 電気学会マグネティックス・リニアドライブ合 同研資, MAG-91-34; LD-91-8, p. 69 (平 3)

(5)「直動システム」, THK(株)カタログ, No.100-1, p. 16 (平元)

（6）日本閵滑学会 編：潤滑ハンドブック，p. 695(昭62) 養㕢堂

(7)「AFCグリース」, THK(株)カタログ, No. 93-1 (昭 63)

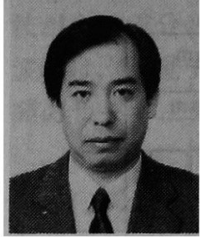

\section{水 野 魅 (正員)}

昭和 33 年 6 月生。 58 年 3 月信州大学 大学院工学研究科電気工学専攻修士課程 修了。同年 4 月 (株)アマダ入社。同社技 術研究所にてリニアモー夕の工作機械, 板金機械への応用に関する研究開発に従事。

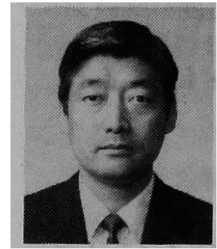

山本栄 (正員)

昭和 24 年 9 月生。 53 年東京商船大学 大学院商船学専攻修士課程修了。同年 4 月(株)アマダ入社。塑性加工およびリニ アモータの研究後, 平成元年アジア金属 工業に移籍，現在に至る。

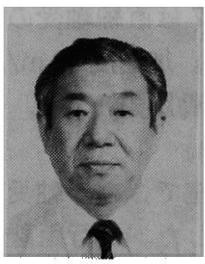

山田 - (正員)

昭和 8 年 4 月生。 34 年東京工業大学 大学院修士課程修了。34 年信州大学工 学部電気工学科助手, 41 年同助教授, 59 年同教授。工学博士。磁気回路解析 を研究の中心に据えてリニアモータ, 磁気センサと電磁型 人工心臓の研究に従事。「日本国際賞」推薦委員, 広島大 学医学部教授 (併任)。 